ISSN 1392-3196 / e-ISSN 2335-8947

Zemdirbyste-Agriculture, vol. 101, No. 4 (2014), p. 355-366

DOI 10.13080/z-a.2014.101.045

\title{
Effect of freshwater sapropel on plants in respect to its growth- affecting activity and cultivable microorganism content
}

\author{
Lelde GRANTINA-IEVINA, Andis KARLSONS, Una ANDERSONE-OZOLA, \\ Gederts IEVINSH \\ University of Latvia \\ 4 Kronvalda blvd., 1586 Riga, Latvia \\ E-mail: gederts@lanet.lv
}

\begin{abstract}
A positive effect of organic-rich sediments sapropels on plant growth has been suggested in general, but has not been proven on an experimental basis. The aim of the present investigation was to study biological activity of freshwater sapropel and its product including analyses of plant growth-affecting activity and cultivable microorganisms. Besides mineral nutrients, sapropel contained unspecified substances promoting plant growth in a seedling growth test with beetroot, Swedish turnip, carrot and tomato. Summed plant growth-affecting activity of sapropel and sapropel-containing substrate BioDeposit Agro had a relatively high growth-enhancing component together with an extremely low growth-inhibiting component. Substrate amendment with BioDeposit Agro resulted in a significant increase in dry matter accumulation only in lettuce plants but not in winter rye plants. High level of aerobic heterotrophic bacteria, high level of yeasts and variable level of filamentous fungi with a low diversity were found in all sapropel samples tested. Plant growth-stimulating activity negatively correlated with the number of colony forming units of both yeasts and fungi. There was no correlation between the number of bacteria and plant growth-stimulating activity.
\end{abstract}

Key words: cultivable microorganisms, organic fertilizer, plant growth stimulation, sapropel, soil amendment.

\section{Introduction}

One of the needs for sustainable agriculture is development and use of plant fertilizers on the basis of organic waste and renewable natural resources. In this respect, organic fertilizers are of great interest. Traditionally, different types of organic fertilizers, e.g., manure, compost, and, recently, vermicompost, have been used. Sapropel is another type of organic fertilizer with a high potential for use in agriculture. In scientific literature, the term "sapropel" has been used mostly in a generic sense for describing organic-rich fine-grained sediments deposited in stagnant water (Emeis, Weissert, 2009). In respect to physical and chemical properties, sapropels are diverse materials with different content of organic substances and mineral nutrient concentration. Among them, the Mediterranean and Black Sea sapropels are the best characterized. In addition, freshwater sapropels, accumulating in lakes of temperate zone, represent highly potential source of organic fertilizer. There are a number of commercially available sapropel-based substrates for plant cultivation in the market. However, studies on use of sapropel-like fertilizers in agriculture are extremely scarce (Terziev et al., 2007; Baksiene, 2009; Nikolov, Shaban, 2011).

Potential general benefits for plants of using sapropel as a fertilizer may include (i) rise in soil organic matter, (ii) stimulation of microbiological activity, (iii) increased amount of plant-available mineral nutrients due to the complex activity of the both previous factors. As related to different (usually low) level of mineralization in sapropel samples (ranging from $10 \%$ to $75 \%$ ), their use as fertilizers for short-term effects of plants seems problematic. However, organic fertilizers can have more specific effect on plants related to plant growth stimulation through action of hormone-like substances (Arthur et al., 2007). Therefore, possible plant growth-affecting activity due to the high content of humic substances in sapropels can be beneficial (Xu et al., 2012). In addition, the content of organic substances with potential physiological activity in freshwater sapropel is relatively high. Thus, the concentrations of different vitamins in sapropel are 4to 25-fold that in soils of medium fertility (Liužinas et al., 2005). A positive effect of sapropels on plant growth has been suggested in general (Angelova et al., 2008), but it has not been proven on an experimental basis. Similarly, while some field studies indicate beneficial long-term effects of sapropel use on crop productivity (Baksiene, 2009); no physiological studies aiming at understanding of mechanisms of the beneficial effects of sapropel application have been performed. It is important that plant growth-affecting activity of organic fertilizers can be evaluated only when appropriate control as a treatment with optimum mineral nutrient level is used for comparison.

Microorganisms in organic fertilizers are an important component of their effect. Thus, plant growthaffecting activity of organic substrates has been associated 
with the presence of beneficial soil microorganisms that are responsible for nitrification, denitrification, solubilization of phosphorus like it has been proved in the case of vermicomposts (Fritz et al., 2012). It is known that Mediterranean sapropels contain green nonsulphur bacteria and crenarchaeota (Coolen et al., 2002). Due to the limited cultivation possibilities of these microorganisms, the number of viable cells is reported to be up to 1500 cells $\mathrm{g}^{-1}$ sediment (Overmann et al., 1999) or much higher when specific media were used, up to 1.0 $\times 10^{7}$ oxic most probable number counts $\mathrm{cm}^{-3}$ on various substrates predominating by facultative anaerobes or aerobes such as Micrococcus sp., Rhodococcus sp., Agrobacterium-related organisms (Süss et al., 2004). The level of bacterial load in freshwater lake sediments has been reported to be similarly high. The level of aerobic heterotrophic bacteria of several lakes of Latvia has been reported to be 0.09 to $22 \times 10^{6}$ cells cm$^{-3}$ (Dzyuban, 2002). Other microbial groups represented in lake sediments are zoosporic fungi and yeasts (Wurzbacher et al., 2010).

So far, no comparative studies with plants in controlled conditions against known level of substrate mineral availability have been performed for sapropels or sapropel-derived substrates. The aim of the present investigation was to study biological activity of freshwater sapropel and its product including analyses of plant growth-affecting activity and cultivable microorganisms.

\section{Material and methods}

Sapropel samples and plants. Commercially available sapropel-based substrate BioDeposit Agro (BDA) produced through addition of native sapropel to heat-treated natural peat was used in the present study. The investigation was carried out at the Faculty of Biology, University of Latvia, Riga, in 2012. Besides, both native (SAPR) and cavitated (SAPRC) sapropel samples were used for analysis of microbiological diversity and plant growth-affecting activity. All samples were donated by LatPower Ltd., Latvia. Characteristics of the native sapropel used for preparation of BDA are given in Table 1 and these of BDA in Table 2. Sapropel and sapropel-containing samples were mixed with water in the ratio $1: 1(\mathrm{v} / \mathrm{v})$ and incubated for $4 \mathrm{~h}$ at room temperature. The mixture was filtrated through a paper filter and used as a 50\% extract. Respective $10 \%$ extract was prepared by mixing 50\% extract with water (1:4, $\mathrm{v} / \mathrm{v})$. For seedling growth tests, beetroot (Beta vulgaris L.) cv. 'Cylindra', Swedish turnip (Brassica napus var. napobrassica L.) cv. 'Golden Ball', carrot (Daucus carota L.) cv. 'Nantes 4', and tomato (Lycopersicon esculentum L.) cv. 'Marmande' seedlings were used. For substrate substitution experiments, winter rye (Secale cereale L.) cv. 'Kier' and lettuce (Lactuca sativa L.) cv. 'Amerikanischer Brauner' plants were used. Seeds were obtained from the local suppliers.

Plant growth-affecting activity. A potential plant growth-affecting activity of sapropel and BDA extracts was measured as described previously by seedling growth tests (Ievinsh, 2011; Grantina-Ievina et al., 2013). Seeds were imbibed in water or respective extract for $4 \mathrm{~h}$.
Table 1. Characteristics of sapropel sample according to the certified analysis

\begin{tabular}{ccc}
\hline Parameter & Unit & Value \\
\hline Organic matter & $\%$ & $73.3 \pm 0.9$ \\
Total $\mathrm{P}\left(\mathrm{P}_{2} \mathrm{O}_{5}\right)$ & $\%$ & $0.15 \pm 0.02$ \\
Total N & $\%$ & $2.8 \pm 0.3$ \\
$\mathrm{~K}$ & $\%$ & $0.22 \pm 0.01$ \\
$\mathrm{As}$ & $\mathrm{mg} \mathrm{kg}^{-1}$ & $0.73 \pm 0.07$ \\
$\mathrm{Fe}$ & $\mathrm{mg} \mathrm{kg}^{-1}$ & $7745 \pm 775$ \\
$\mathrm{Hg}$ & $\mathrm{mg} \mathrm{kg}^{-1}$ & $0.30 \pm 0.04$ \\
$\mathrm{Cr}$ & $\mathrm{mg} \mathrm{kg}^{-1}$ & $23 \pm 2$ \\
$\mathrm{Cd}$ & $\mathrm{mg} \mathrm{kg}^{-1}$ & $1.1 \pm 0.1$ \\
$\mathrm{Ni}$ & $\mathrm{mg} \mathrm{kg}^{-1}$ & $18 \pm 1$ \\
$\mathrm{~Pb}$ & $\mathrm{mg} \mathrm{kg}^{-1}$ & $9.5 \pm 0.1$ \\
$\mathrm{Cu}$ & $\mathrm{mg} \mathrm{kg}^{-1}$ & $23 \pm 2$ \\
\hline
\end{tabular}

Note. Contents are given on a fresh mass basis.

Table 2. Characteristics of BioDeposit Agro (BDA) sample according to the certified analysis

\begin{tabular}{ccc}
\hline Parameter & Unit & Value \\
\hline Organic matter & $\%$ & $93.6 \pm 1.0$ \\
Total $\mathrm{P}_{\left(\mathrm{P}_{2} \mathrm{O}_{5}\right)}$ & $\%$ & $0.040 \pm 0.004$ \\
Total N & $\%$ & $1.6 \pm 0.2$ \\
Total C & $\%$ & $64 \pm 6$ \\
$\mathrm{~K}$ & $\%$ & $0.038 \pm 0.008$ \\
Total S & $\mathrm{g} \mathrm{kg}^{-1}$ & $1.1 \pm 0.1$ \\
$\mathrm{CaO}$ & $\mathrm{g} \mathrm{kg}^{-1}$ & $7.0 \pm 0.1$ \\
$\mathrm{MgO}$ & $\mathrm{g} \mathrm{kg}^{-1}$ & $1.74 \pm 0.14$ \\
$\mathrm{Mn}$ & $\mathrm{mg} \mathrm{kg}^{-1}$ & $32 \pm 2$ \\
$\mathrm{~B}$ & $\mathrm{mg} \mathrm{kg}^{-1}$ & $8.52 \pm 0.14$ \\
Humic acids & $\%$ & 5.4 \\
Fulvic acids & $\%$ & 10.1 \\
\hline
\end{tabular}

Note. Contents are given on a fresh mass basis.

Imbibed seeds were placed on Petri dishes (30 seeds per plate, in five replicates) on a filter paper soaked with the respective solution. The dishes were incubated for six days at $23 \pm 2{ }^{\circ} \mathrm{C}$ in darkness. The height of hypocotyl and the length of radicle were measured. Potential growth affecting activity was expressed as a percentage of change in length in respect to seedlings grown from water imbibed seeds. Summed growth stimulating and inhibiting activity was calculated by adding together all percentages of stimulating and inhibiting activity separately for all vegetable species tested (both hypocotyl and radicle response) at both concentrations used.

Analysis of plant-available mineral nutrients. For analysis of plant-available inorganic nutrients, a sample $(50 \mathrm{ml})$ of BDA was homogenized in $250 \mathrm{ml} 1 \mathrm{M}$ $\mathrm{HCl}$ for $1 \mathrm{~h}$ and filtered though the filter paper. The level of nitrogen $(\mathrm{N})$, phosphorus (P), molybdenum (Mo) and boron (B) was estimated by colorimetry; calcium (Ca), magnesium $(\mathrm{Mg})$, iron $(\mathrm{Fe})$, cuprum $(\mathrm{Cu})$, zinc $(\mathrm{Zn})$ and manganese $(\mathrm{Mn})$ were measured by atomic absorption spectrophotometer "AAnalyst 700" ("Perkin Elmer", USA) (acetylene-air flame); the amount of sulphur (S) was assessed by turbidimetry and potassium $(\mathrm{K})$ by flame photometry PFP7 ("Jenway", UK) (air-propanebutane flame). 
Substrate substitution experiments. Substrate used for cultivation of winter rye and lettuce plants was pure quartz sand or quartz sand enriched with mineral nutrients at the level optimal for the majority of cultivated plants (Osvalde, 2011). For both types of substrate, pure BDA was added to pure sand as well as sand enriched with mineral nutrients, and BDA enriched with mineral nutrients were added to sand enriched with mineral nutrients at three concentrations $(10,20$ and $40 \%$; v/v) resulting in 12 different treatments (Table 3 ). Substrates without BDA were used as controls. Waterimbibed seeds of winter rye and lettuce were sown in 8 $\times 8 \times 12 \mathrm{~cm}$ plastic containers, nine seeds per container, five containers per treatment. Substrate was adjusted to $60 \pm 5 \%$ water holding capacity with deionized water maintained throughout the study. Containers were randomly arranged in a growth cabinet with a 16/8 h light/dark cycle, photosynthetically active radiation with a photon flux density of $150 \mu \mathrm{mol} \mathrm{m} \mathrm{m}^{-2} \mathrm{~s}^{-1}$. Average temperature was $22 / 15^{\circ} \mathrm{C}$ (day/night), relative humidity $60 \%$. Plants were thinned to five individuals per container one week after emergence. Winter rye plants were cultivated for five weeks, lettuce plants for ten weeks.

Table 3. Plant-available mineral nutrient concentration in sapropel-containing organic fertilizer BioDeposit Agro (BDA) in respect to approximate optimum nutrient concentrations in substrate for cultivated plants (Osvalde, 2011)

\begin{tabular}{ccccc}
\hline Nutrient & $\begin{array}{c}\text { BDA } \\
\mathrm{mg} \mathrm{L}^{-1}\end{array}$ & $\begin{array}{c}\text { Mineral- } \\
\text { enriched } \\
\text { BDA } \\
\mathrm{mg} \mathrm{L}^{-1}\end{array}$ & $\begin{array}{c}\text { Mineral- } \\
\text { enriched } \\
\text { sand } \\
\mathrm{mg} \mathrm{L}^{-1}\end{array}$ & $\begin{array}{c}\text { Optimum } \\
\text { for plants } \\
\mathrm{mg} \mathrm{L}^{-1}\end{array}$ \\
\hline $\mathrm{N}$ & $118 \pm 34$ & 150 & 120 & 120 \\
$\mathrm{P}$ & $49 \pm 158$ & 130 & 60 & 60 \\
$\mathrm{~K}$ & $113 \pm 163$ & 330 & 150 & 150 \\
$\mathrm{Ca}$ & $5700 \pm 1069$ & 5700 & 800 & 800 \\
$\mathrm{Mg}$ & $3515 \pm 232$ & 3515 & 50 & 50 \\
$\mathrm{~S}$ & $9 \pm 26$ & 60 & 50 & 50 \\
$\mathrm{Fe}$ & $440 \pm 176$ & 440 & 30 & 30 \\
$\mathrm{Mn}$ & $25.5 \pm 14$ & 25.5 & 1.5 & 1.5 \\
$\mathrm{Zn}$ & $315 \pm 44$ & 315 & 1 & 1 \\
$\mathrm{Cu}$ & $7.7 \pm 4.0$ & 7.7 & 0.5 & 0.5 \\
$\mathrm{Mo}$ & $0.09 \pm 0.00$ & 0.09 & 0.02 & 0.02 \\
$\mathrm{~B}$ & $0.10 \pm 0.4$ & 1.5 & 0.2 & 0.2 \\
\hline
\end{tabular}

Note. Values for BDA are the means \pm SEM of three replicates.

Measurement of leaf chlorophyll content and chlorophyll a fluorescence. To characterize physiological status of winter rye and lettuce plants during growth, photosynthesis-related parameters were analyzed. Chlorophyll content and chlorophyll $a$ fluorescence were measured for four-week-old winter rye and five-week-old lettuce plants. Leaf chlorophyll content was measured nondestructively by means of a chlorophyll meter SPAD 502 ("Konica-Minolta", Japan). Six independent measurements over individual plant were performed for every treatment. For each measurement, five readings were made over the length of the leaf blade (winter rye) or leaf (lettuce) and average value was registered using internal function of the chlorophyll meter. Chlorophyll $a$ fluorescence was measured by continuous measurement method using fluorometer "Handy PEA" ("Hansatech", UK). Individual leaves from six plants per treatment were darkened by standard leaf clips for not less than $20 \mathrm{~min}$ and fast fluorescence kinetics was recorded for $1 \mathrm{~s}$ following illumination with saturating light pulse $\left(3500 \mu \mathrm{mol} \mathrm{m} \mathrm{m}^{-2} \mathrm{~s}^{-1}\right)$. Overall efficiency of photosystem II photochemistry was characterized using a complex parameter performance index, combining three independent values (Appenroth et al., 2001).

Analysis of cultivable microorganisms. In order to estimate the number of colony forming units (CFU) of cultivable filamentous fungi, yeasts and bacteria by a plate count method the sample dilutions were prepared by adding $10 \mathrm{~g}$ of sample to $90 \mathrm{ml}$ of sterile distilled water. Each sample was analyzed in two replicates. Suspensions were homogenized $1 \mathrm{~h}$ on horizontal shaker. After that serial dilutions were prepared, and $0.1 \mathrm{ml}$ of dilutions $10^{-2}, 10^{-3}, 10^{-4}, 10^{-5}$ and $10^{-6}$ were analyzed. Total number of bacteria was estimated after three days of incubation on agarised Tryptic soy broth ("Biolife Italiana", Italy) at $20 \pm 2^{\circ} \mathrm{C}$. Total numbers of cultivable filamentous fungi and yeasts were estimated after 5 days of incubation on Rose Bengal agar (RBA) with chloramphenicol ("Biolife Italiana") at $20 \pm 2^{\circ} \mathrm{C}$. Number of cultivable microorganisms was expressed on dry mass (DM) basis.

Statistical analysis. Significance of differences between means was determined by the Tukey-Kramer test at the $\alpha=0.05$ level. Correlation analysis was performed with Excel ("Microsoft", USA). Significance was evaluated at $p<0.05$ level. Both Pearson correlation coefficients $(r)$ and determination coefficients $\left(R^{2}\right)$ were determined.

\section{Results}

Plant growth-affecting activity. Water extracts of all tested materials significantly promoted growth of both hypocotyl (Fig. 1) and radicle (Fig. 2) of beetroot, Swedish turnip, carrot and tomato seedlings. In general, radicle growth was significantly more stimulated by $10 \%$ BDA in comparison to hypocotyl growth except tomato seedlings. No significant difference between tested materials in respect to hypocotyl growth promotion was seen for most concentrations and crop species. However, significant inhibition of radicle growth was evident when beetroot and Swedish turnip seeds were treated with $50 \%$ BDA (Fig. 2 A and B). Summed growth stimulating activity was 655,1136 and $786 \%$ for native sapropel, cavitated sapropel and BDA, respectively. Both sapropel samples exhibited no growth inhibiting activity, while summed inhibiting activity for BDA was $55 \%$.

Substratesubstitution experiments. Substitution of sand with BDA resulted in a near-linear concentrationdependent decrease of germination percentage of winter rye seeds irrespective of the presence of mineral nutrients (Fig. 3 A). The effect was statistically significant 


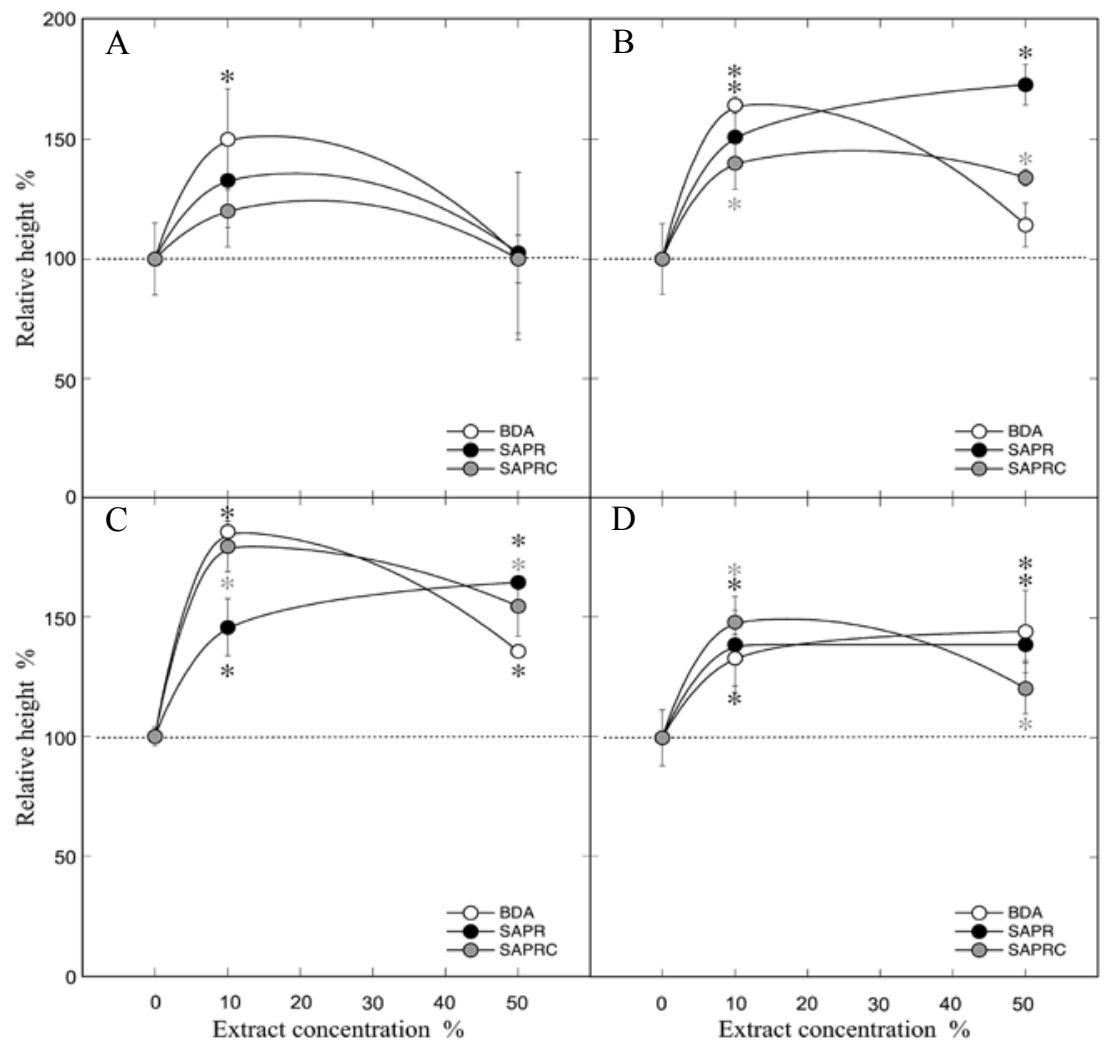

Notes. Data are means \pm SE from five independent measurements with 30 seedlings each. Asterisks indicate statistically significant differences from the respective control, $\alpha=0.05$.

Figure 1. Effect of native (SAPR) and cavitated (SAPRC) sapropel, and BioDeposit Agro (BDA) water extracts on height of hypocotyl of rootbeet (A), Swedish turnip (B), carrot (C) and tomato (D) seedlings
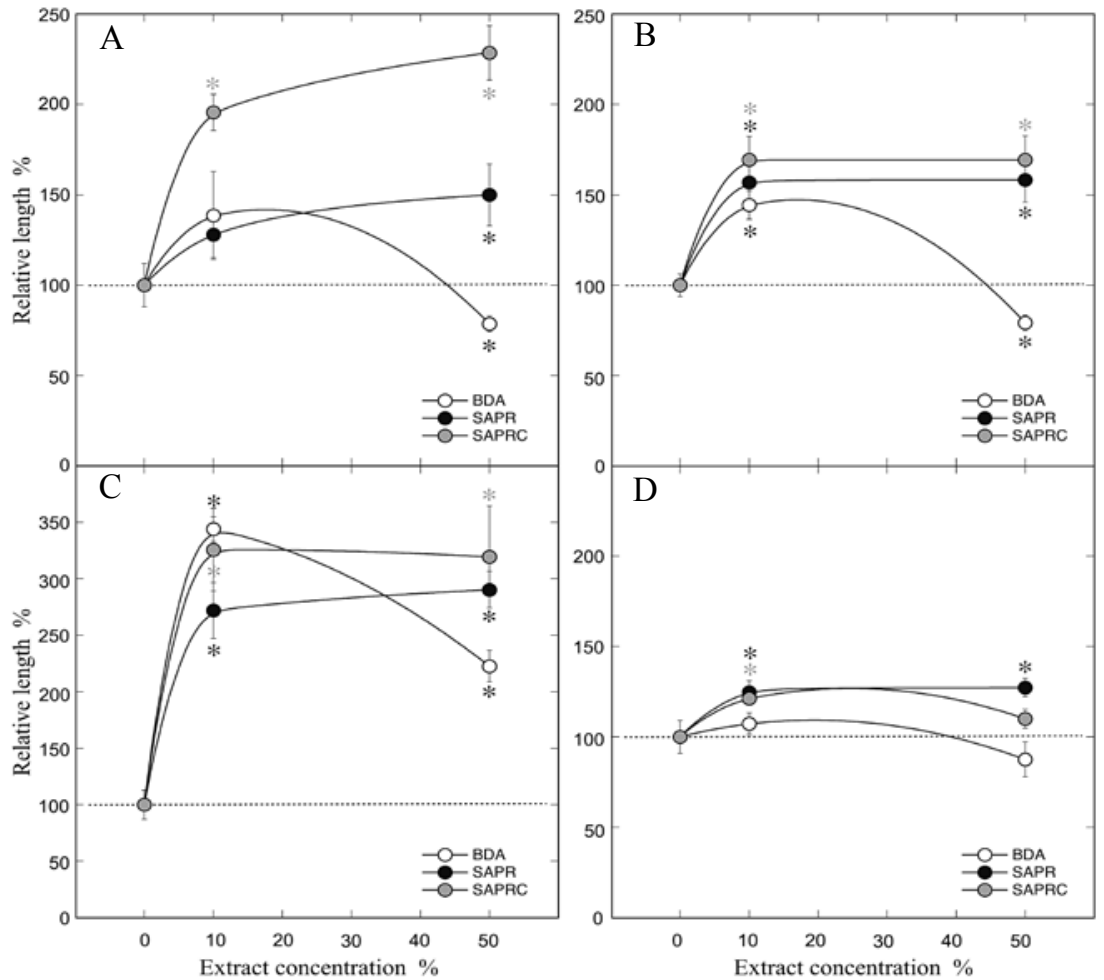

Notes. Data are means \pm SE from five independent measurements with 30 seedlings each. Asterisks indicate statistically significant differences from the respective control, $\alpha=0.05$.

Figure 2. Effect of native (SAPR) and cavitated (SAPRC) sapropel, and BioDeposit Agro (BDA) water extracts on length of radicle of rootbeet (A), Swedish turnip (B), carrot (C) and tomato (D) seedlings 

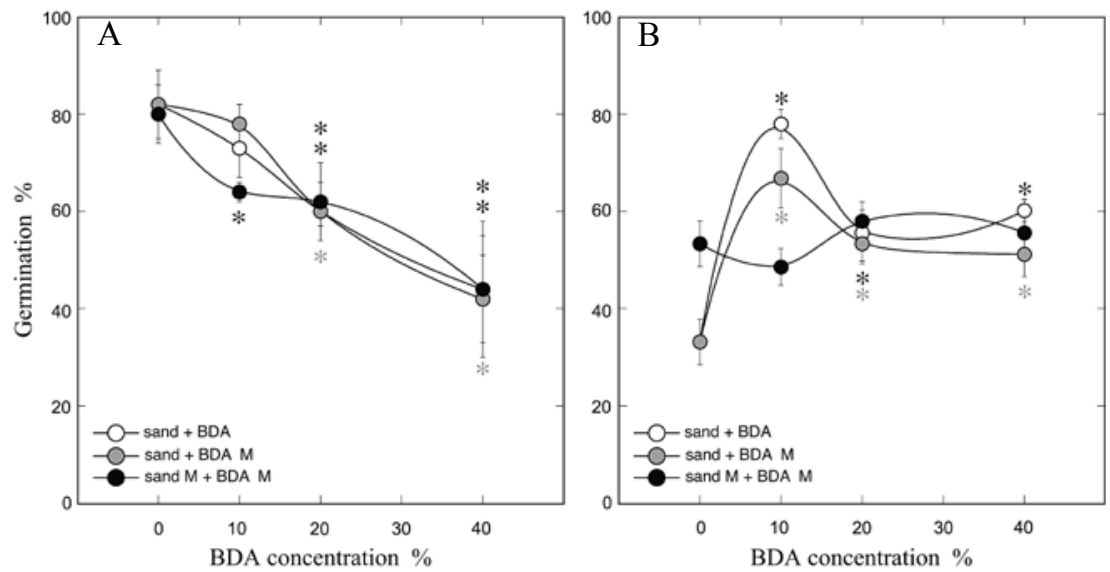

Notes. Sand + BDA - pure quartz sand with BDA, sand + BDA M - pure quartz sand with mineral-enriched BDA, sand M + BDA $\mathrm{M}$ - mineral-enriched sand with mineral-enriched BDA. Data are means $\pm \mathrm{SE}$ from five replications with nine seeds per container each. Asterisks indicate statistically significant differences from the respective control, $\alpha=0.05$.

Figure 3. Effect of substrate substitution with BioDeposit Agro (BDA) on seed germination of winter rye (A) and lettuce (B) plants
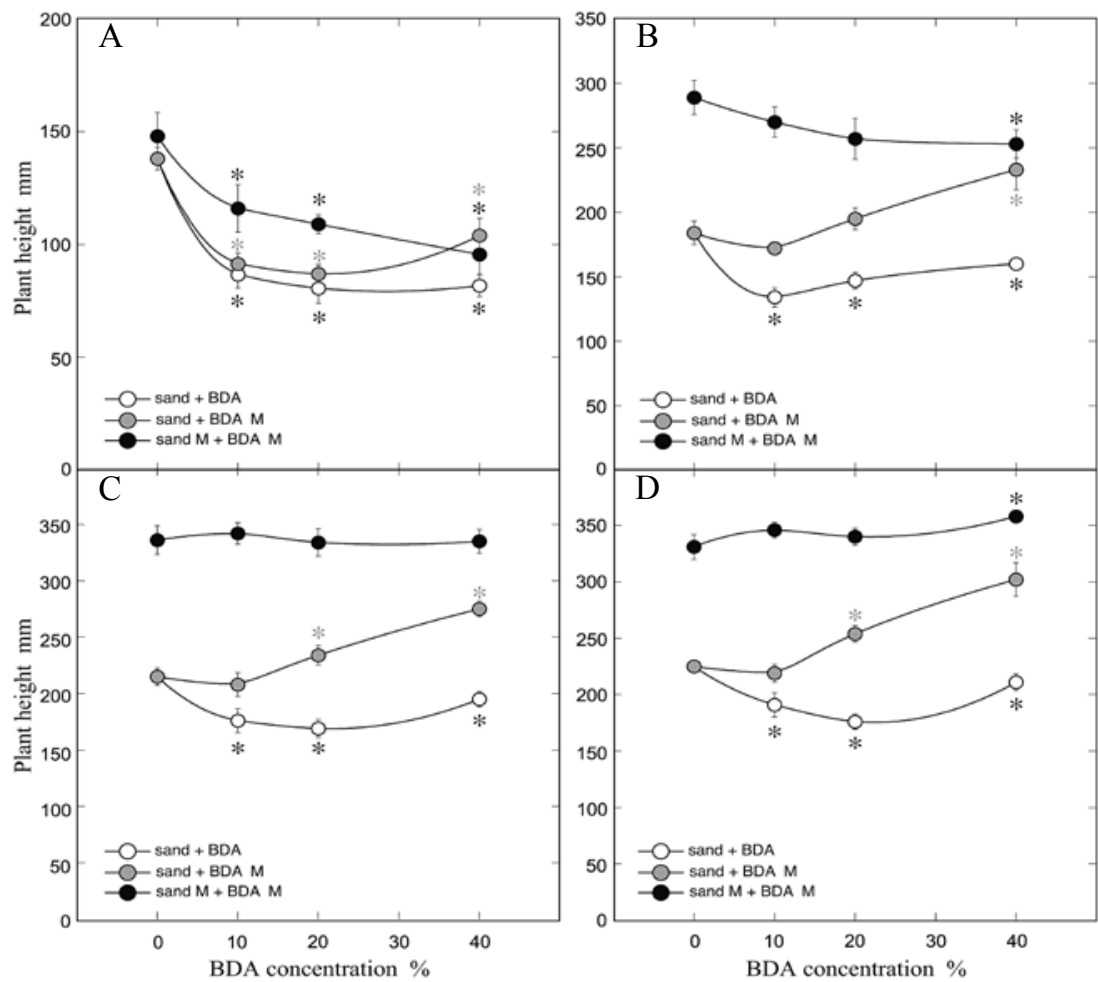

Explanations under Figure 3

Figure 4. Effect of substrate substitution with BioDeposit Agro (BDA) on linear growth of one- (A), two- (B), three(C) and four-week-old winter rye plants

for all treatments starting with $20 \%$ substitution. At $10 \%$ substitution, significant decrease of germination percentage was evident only for mineral-enriched sand substituted with mineral-enriched BDA. Initial effect of sand substitution with BDA was seen as significant concentration-dependent inhibition of linear growth of winter rye plants (Fig. 4 A and B). At the later stages, linear growth of plants was stimulated by BDA substitution only in the case when mineral-enriched BDA was used at $20 \%$ and $40 \%$ concentration (Fig. $4 \mathrm{C}$ and D). However, inhibitory effect was still evident for plant grown in pure sand substituted with pure BDA.
Both fresh and dry matter accumulation in shoots was significantly affected by BDA substitution only for pure sand-grown rye plants treated with mineral-enriched BDA (Fig. $5 \mathrm{~A}$ and C). However, even in the case of maximum growth stimulation by $40 \%$ BDA substitution, plant mass reached only $31 \%$ from that of plants grown in mineral-enriched sand. These differences were reflected also by shoot morphology of plants grown at respective treatments. The effect of BDA on matter accumulation was different in roots. Pure sand substitution with $20 \%$ and $40 \%$ BDA resulted in significant inhibition of both fresh and dry matter accumulation in roots of rye plants (Fig. $5 \mathrm{~B}$ and D). 

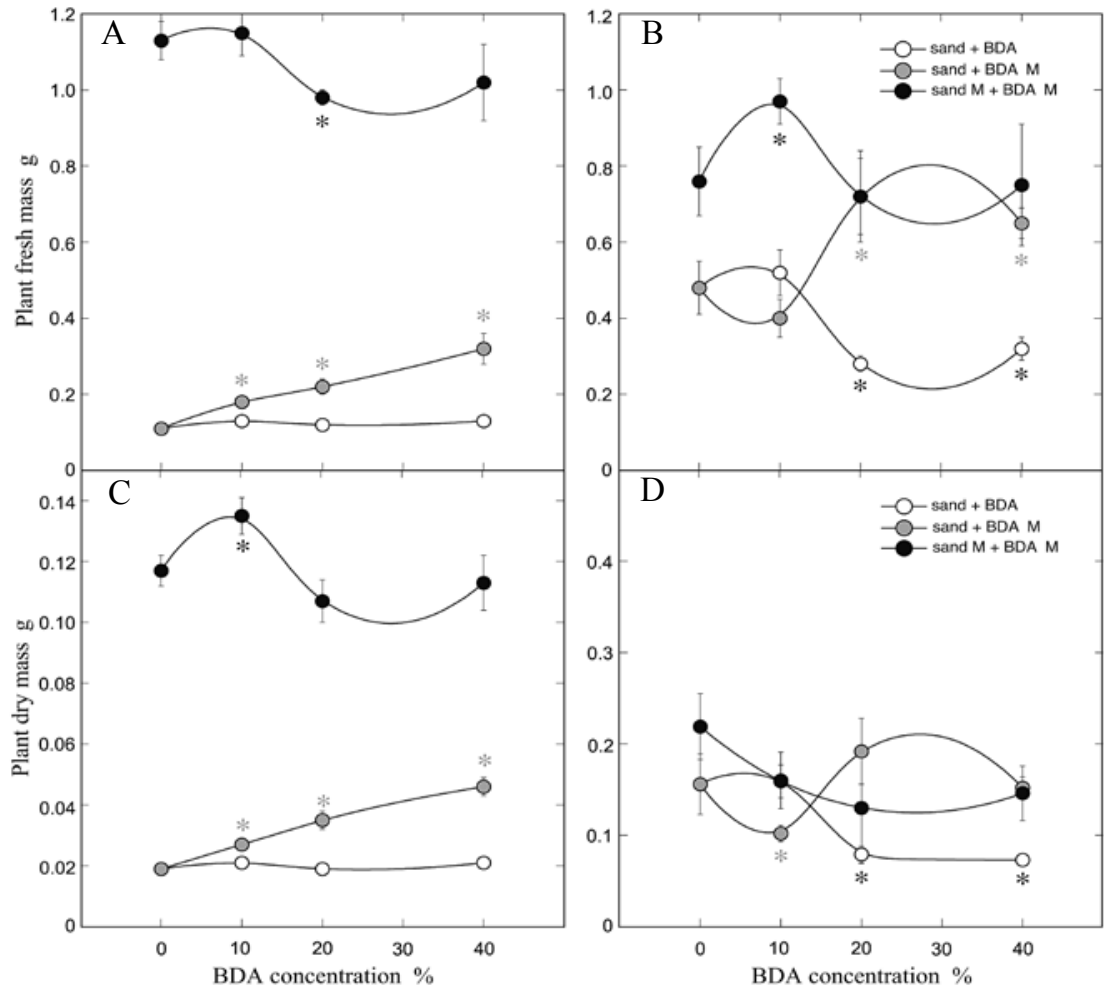

Explanations under Figure 3

Figure 5. Effect of substrate substitution with BioDeposit Agro (BDA) on fresh mass of shoot (A) and roots (B), and dry mass of shoot (C) and roots (D) of individual five-week-old winter rye plants

Photosynthesis-related parameters performance index and chlorophyll content were significantly lower in rye plants grown in pure sand in comparison to those grown in mineral-enriched sand (Fig. 6). Performance index was significantly enhanced by BDA substitution for plants treated with mineral-enriched BDA $(20 \%$ and $40 \%$ ) grown both in pure and mineral-enriched sand (Fig. 6 A). No significant effect was evident for plant grown in pure sand and treated with pure BDA.

In contrast to rye seeds, germination percentage of lettuce seeds was not affected by BDA substitution when mineral-enriched sand was substituted with mineral-enriched substrate (Fig. 3 B). When lettuce seeds were germinated in pure sand, BDA substitution resulted in significant increase in germination percentage for all concentrations with higher effect at 10\% BDA. At $20 \%$ and $40 \%$ substitution, germination percentage was similar for all respective treatments. In addition, it appears that sand enrichment with minerals significantly increased germination percentage of lettuce seeds in control conditions (Fig. 3 B).

Growth of lettuce plants in pure sand was almost completely arrested irrespective of BDA substitution (Figs 7 and 8). In contrast to winter rye plants, BDA
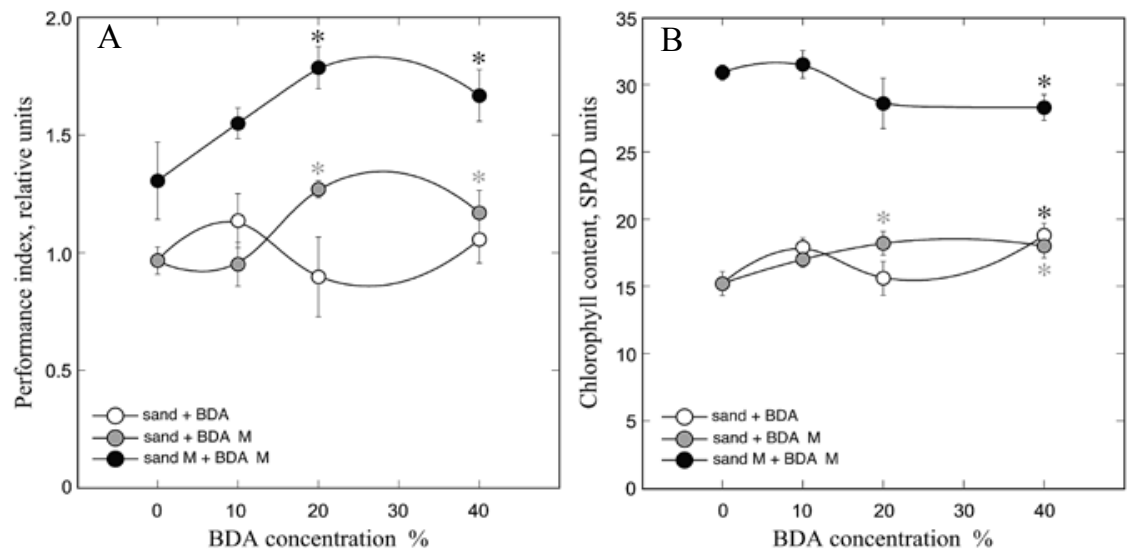

Notes. Sand + BDA - pure quartz sand with BDA, sand + BDA M - pure quartz sand with mineral-enriched BDA, sand M + BDA $\mathrm{M}-$ mineral-enriched sand with mineral-enriched BDA. Data are means \pm SE from six independent measurements per treatment. Asterisks indicate statistically significant differences from the respective control, $\alpha=0.05$.

Figure 6. Effect of substrate substitution with BioDeposit Agro (BDA) on performance index (A) and leaf chlorophyll content (B) of four-week-old winter rye plants 


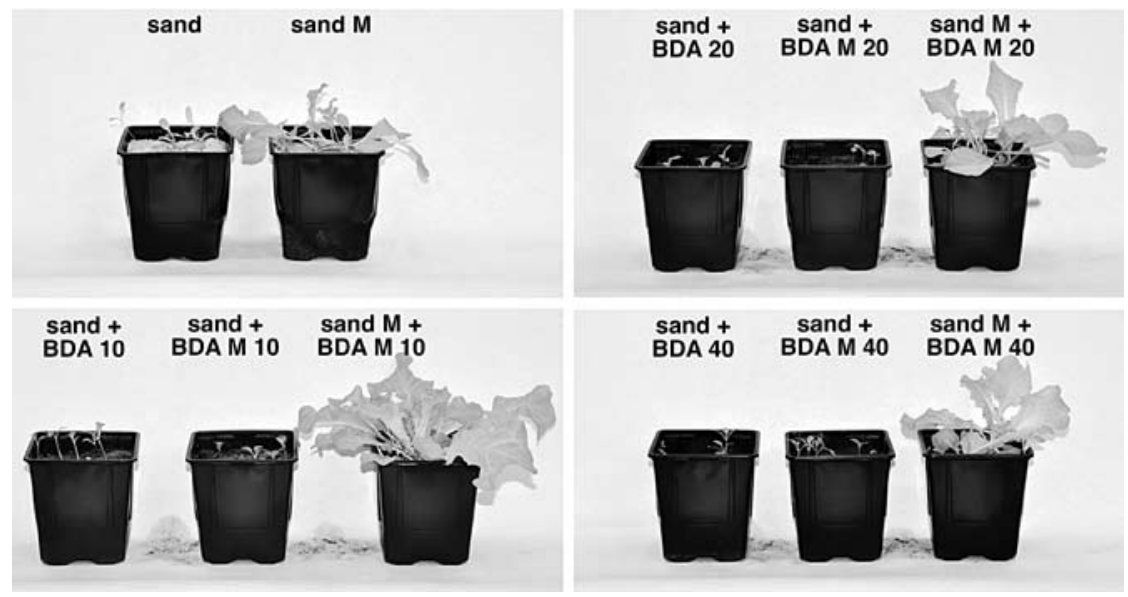

Sand - pure quartz sand, sand M - mineral-enriched quartz sand, sand + BDA - pure sand with BDA, sand + BDA M - pure sand with mineral-enriched BDA, sand M + BDA M - mineral-enriched sand with mineral-enriched BDA

Figure 7. Morphology of representative five-week-old lettuce plants grown with and without BioDeposit Agro (BDA)
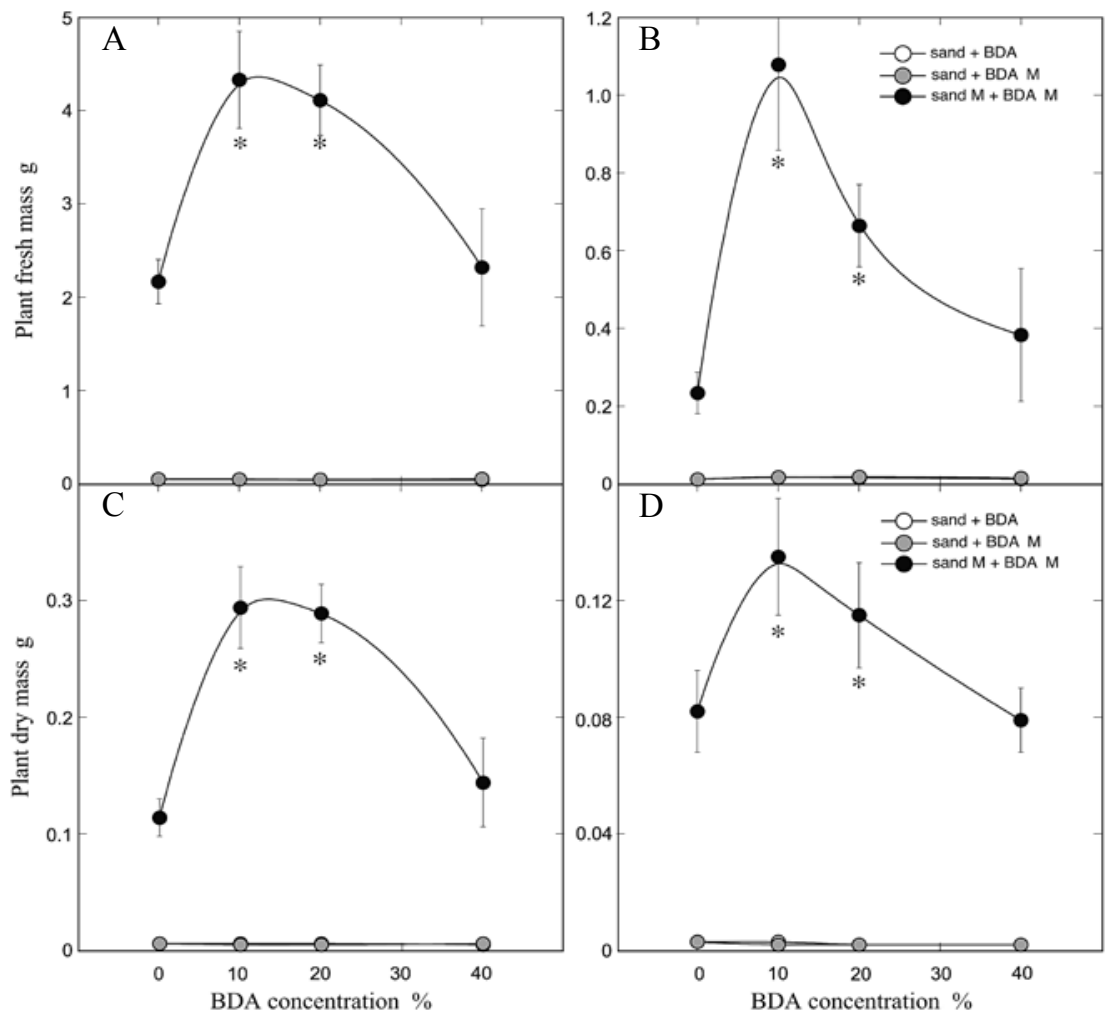

Notes. Sand + BDA - pure quartz sand with BDA, sand + BDA M - pure quartz sand with mineral-enriched BDA, sand M + BDA $\mathrm{M}$ - mineral-enriched sand with mineral-enriched BDA. Data are means $\pm \mathrm{SE}$ from five replications with five plants per container each. Asterisks indicate statistically significant differences from the respective control, $\alpha=0.05$.

Figure 8. Effect of substrate substitution with BioDeposit Agro (BDA) on fresh mass of shoot (A) and roots (B), and dry mass of shoot (C) and roots (D) of individual ten-week-old lettuce plants

substitution at concentration $10 \%$ and $20 \%$ resulted in significant increase in both fresh and dry matter accumulation in shoots and roots of lettuce plants grown in mineral-enriched sand (Fig. 8).

Morphological effects of BDA substitution in lettuce plants were reflected by changes in photosynthesisrelated parameters. BDA substitution at $10 \%$ and $20 \%$ concentration resulted in relatively small but significant increase of performance index in leaves of ten-weekold lettuce plants (Fig. 9 A). Increase in leaf chlorophyll content was relatively more pronounced and was evident at all BDA concentrations used (Fig. 9 B). However, the effect was relatively smaller at $40 \%$ substitution.

Number of cultivable microorganisms. Both sapropel samples had high level of aerobic heterotrophic bacteria: $(1.36 \pm 0.07) \times 10^{6}$ to $(2.46 \pm 0.11) \times 10^{6} \mathrm{CFU}$ $\mathrm{g}^{-1}$ (Fig. 10), but it was significantly lower than in the sapropel-based substrate samples $(2.40 \pm 0.65) \times 10^{7}$ to $(4.71 \pm 0.76) \times 10^{7} \mathrm{CFU} \mathrm{g}^{-1}$. Both samples of sapropel and all sapropel-based substrate samples contained high 

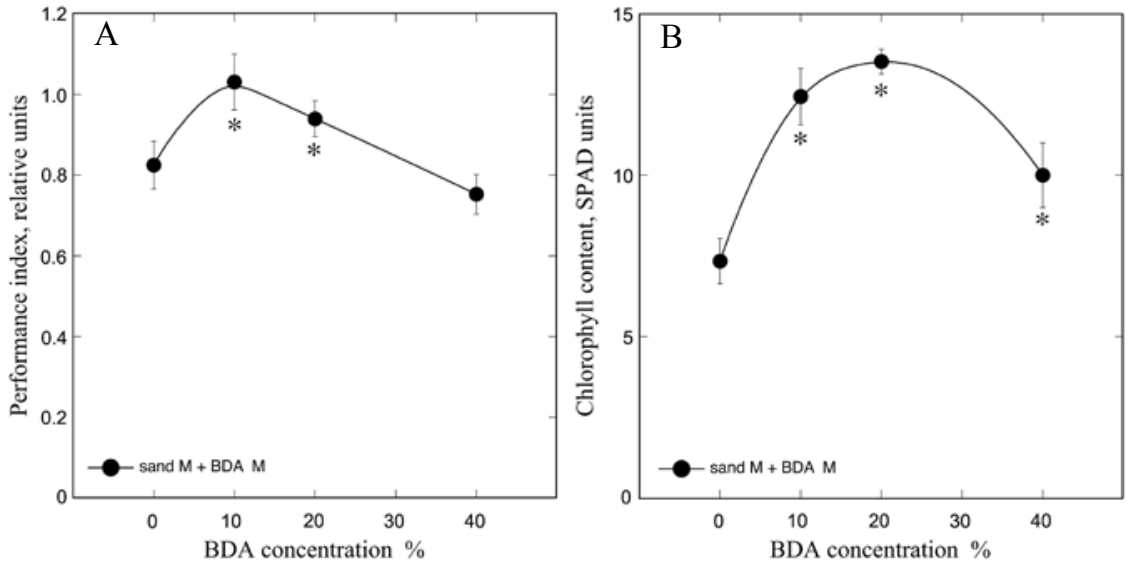

Notes. Sand M + BDA M - mineral-enriched sand with mineral-enriched BDA. Data are means \pm SE from six independent measurements per treatment. No analysis was performed for lettuce plants grown in pure sand due to extremely small leaves not allowing for correct placement of the apporpriate equipment. Asterisks indicate statistically significant differences from the respective control, $\alpha=0.05$.

Figure 9. Effect of substrate substitution with BioDeposit Agro (BDA) on performance index (A) and leaf chlorophyll content (B) of ten-week-old lettuce plants

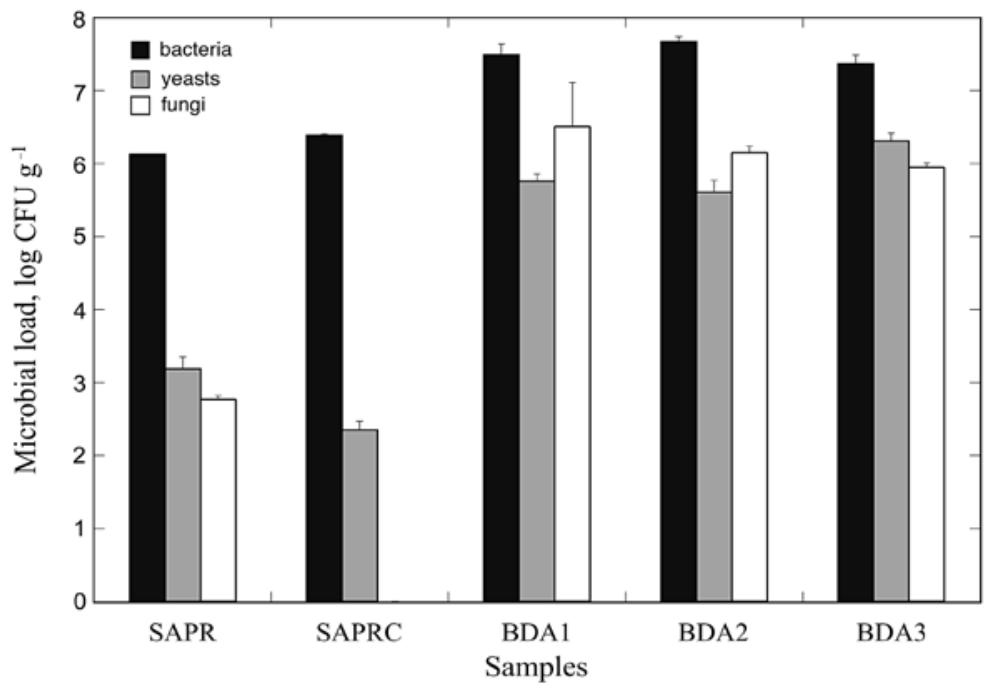

Note. Data are means $\pm \mathrm{SD}$ from two independent measurements; $\mathrm{CFU}$ - colony forming units.

Figure 10. Amount of cultivable bacteria, yeasts and fungi in native (SAPR) and cavitated (SAPRC) sapropel, and different BioDeposit Agro (BDA1, BDA2, BDA3) samples

level of yeasts $(2.28 \pm 0.64) \times 10^{2}$ to $(2.09 \pm 0.54) \times 10^{6}$ $\mathrm{CFU} \mathrm{\textrm {g } ^ { - 1 }}$. The level of yeasts in sapropel-based substrate was significantly higher $(p<0.001)$ than that in sapropel. It is obvious that also the heat-treated natural peat contained high levels of yeasts. Samples of sapropel contained low level of filamentous fungi: 0 to $(5.91 \pm 0.64) \times 10^{2} \mathrm{CFU} \mathrm{g}^{-1}$, but sapropel-based substrates had high level of filamentous fungi: $(8.91 \pm 1.16) \times 10^{5}$ to $(4.89 \pm 5.18) \times 10^{6} \mathrm{CFU} \mathrm{g}^{-1}$. However, fungal diversity was low as representatives of only three to four genera were found. Relatively small number of CFU was found for Penicillium spp. in native sapropel sample but not in cavitated sapropel sample. In native sapropel white sterile basidiomycete fungi were detected. No Trichoderma and Mortierella isolates were present in the analyzed samples.

Using a correlation analysis it was detected that plant growth stimulating activity negatively correlated with the number of both yeasts $\left(r=-0.47, R^{2}=0.22\right)$ and fungi ( $r=-0.66, R^{2}=0.43$ ). There were no correlation between the number of bacteria and plant growth stimulating activity.

\section{Discussion}

Plant growth-affecting activity of sapropelcontaining material was clearly plant species-specific, as different morphological responses to increasing substrate concentration ofBDA were recorded for winter rye $v s$ lettuce plants. Also, in seedling tests, beetroot seedlings showed the less positive response in respect to hypocotyl growth (Fig. 2 A) and carrot seedlings were the least responsive in respect to radicle growth (Fig. 3 D). Summed growth stimulating activity of sapropel-containing substrates can be characterized as relatively high, when compared to other organic fertilizers (Grantina-Ievina et al., 2013). However, summed growth inhibiting activity was absent 
in both sapropel samples and extremely low in BDA, as compared to average growth inhibiting activity of $149 \%$ in other fertilizer samples (Grantina-Ievina et al., 2013).

In contrast to other organic fertilizer, vermicompost, containing a high level of plant-available mineral nutrients (Orozco et al., 1996), sapropel-based fertilizer BDA contained only relatively low levels of N, P, K, S and B (Table 1). However, concentrations of $\mathrm{Ca}, \mathrm{Mg}, \mathrm{Fe}, \mathrm{Mn}, \mathrm{Zn}, \mathrm{Cu}$ and Mo were comparable to these found in majority of organic fertilizers (Chaoui et al., 2003). Consequently, sapropel could not provide balanced plant nutrition even at a high rate of substrate substitution.

For pure sand-grown winter rye plants, increase in linear growth and shoot dry matter accumulation by substitution with mineral-enriched BDA clearly reflected the direct effect of increased mineral nutrient availability. Any significant positive effect of growth-promoting substances can be excluded as no consistent effect of BDA substitution was evident in mineral-enriched sandgrown rye plants. In contrast, increase in accumulation of both fresh and dry matter in mineral-enriched sand-grown lettuce plants was due to the growth-promoting activity of BDA substitution or other positive physiological effects. Non-nutrient stimulation of plant growth by organic fertilizers is usually attributed to humic substances (Tomati et al., 1988) and plant hormones (Arthur et al., 2007). Sapropel is a rich source of both humic substances (Klavins et al., 2003) as well as plant hormones (Szajdak, Maryganova, 2007) most probably acting as a growth stimulants on lettuce plants in the present study. Fresh matter accumulation in roots of lettuce plants grown in BDA-substituted substrate was in part due to higher water content, as dry matter accumulation was considerably less-affected (Fig. 10). Similar effect has been noted also in humic acid-treated plants (Piccolo et al., 1993).

No apparent stress conditions resulted from substrate substitution with even $40 \%$ BDA, as no decrease in chlorophyll fluorescence parameter performance index and leaf chlorophyll content was evident (Figs 6 and 9) indirectly indicating no toxic effect of heavy metals. In contrast, at the optimum level of mineral availability, BDA substitution resulted in significant increase in performance index both for rye plants (at 20\% and $40 \%$ ) and lettuce plants (at 10\% and 20\%). Also, leaf chlorophyll content significantly increased in lettuce plants at all BDA concentrations used. However, the two crop species differed in respect to potential effect of BDA substitution on dry matter accumulation in conditions of optimum mineral supply: it was stimulated at $10 \%$ and $20 \%$ for lettuce plants both at shoot and root level, while significant positive effect on shoot growth for rye plants was evident only at $10 \%$ substitution.

Among different organic fertilizers, both microbiological diversity and plant growth-affecting activity has been thoroughly characterized for earthwormderived vermicompost (Ievinsh, 2011; Grantina-Ievina et al., 2013). In the present study, microbiological diversity and possible plant growth-affecting activity of sapropel-containing substrate were analyzed. When compared to other organic fertilizers, sapropel showed clearly distinctive microbiological composition (Grantina-Ievina et al., 2013). Summed plant growthaffecting activity of sapropel and sapropel-containing substrate BDA had relatively high growth-enhancing component together with extremely low growthinhibiting component. Consequently, certain chemical constituents in sapropel exhibit plant growth stimulating activity. Changes of different aspects of chemical composition in lake sediments forming sapropel depend on microbiological activity through mineralization, nitrification, denitrification, methane production, and sulphate reduction (Kuznetsov, 1975). On the other hand, plant growth-affecting activity of organic fertilizers has been associated with the presence of beneficial microorganisms. Thus, the total number of cultivable filamentous fungi had significant positive impact on plant growth-stimulating activity of vermicompost samples (Grantina-Ievina et al., 2013). In particular, Trichoderma spp. and Mortierella spp. in organic fertilizers were considered as plant growth-promoting fungi. Although, no Trichoderma and Mortierella were isolated from sapropel and BDA samples in the present investigation. This can explain why the correlation between the number of fungal CFU and plant growth stimulating activity was negative. It seems that lake sapropel does not contain any plant growth promoting fungi.

The presence of at least part of yeasts found in BDA can be due to the addition of natural peat to sapropel, as it is reported in other studies that both natural Antarctic peat contains high levels $\left(3.00 \times 10^{6} \mathrm{~g}^{-1}\right.$ dry mass) of yeasts (Baker, 1970) and peat of temperate climate origin (including samples from Latvia) contains high levels of yeasts identified as basidiomycete yeasts (Hunter et al., 2006). Also, a high number of filamentous fungi found in sapropel-based substrate BDA is characteristic for peats (Hunter et al. 2006). The number of aerobic heterotrophic bacteria found in both sapropel samples is within the range reported in the investigation about several lakes of Latvia (Dzyuban, 2002). In other studies using mud (sapropel) samples from various lakes in Latvia it has been found that sapropel from all lakes contained sulphate-reducing bacteria, heterotrophic, saprophytic and mesophilic bacteria (Silamiksele et al., unpublished results). Identified species belonged to $\alpha$-, $\beta$ and $\delta$-Proteobacteria, Actinobacteria, Clostridia, Bacilli and Flavobacteria (Silamiķele et al., unpublished results). Also, sapropel from all lakes contained such bacterial species as Burkholderia cepacia, Bacillus licheniformis and Sphingomonas paucimobilis (Silamiksele et al., unpublished results). It is reported that B. cepacia isolated from the rhyzosphere of maize showed both antifungal and plant growth-promoting activity (Bevivino et al., 1998). B. licheniformis also exhibit an antifungal activity against plant pathogenic fungi (Lee et al., 2006). S. paucimobilis is reported to represent a cadmium 
resistant bacteria (Prapagdee et al., 2013), and the native sapropel tested contained cadmium in the concentration of $1.1 \mathrm{mg} \mathrm{kg}^{-1}$.

Positive effect on soil fertility is probably one of most important beneficial long term effects of sapropel application. In a long term (more than 10 years) study by Baksiene (2009) it was revealed that application of lake sediments sapropel positively affected soil physical properties and, as a result, increased crop productivity by $8 \%$ to $30 \%$. It appears that possible short-term beneficial effect of substrate amendment with sapropel-containing organic fertilizer clearly depends on plant species. Due to the relatively low mineral nutrient content of sapropel, it is advisable to use this type of organic fertilizer in conditions of near-optimum mineral nutrient availability, i.e. through enrichment with necessary minerals. However, long-term benefits of sapropel use for plants can be possibly achieved through overall increase of soil fertility. Further studies with different plant species, soil conditions and mineral nutrient availability levels are necessary in order to better understand possible benefits from practical use of sapropel-based organic fertilizers.

\section{Conclusions}

1. Freshwater sapropel samples as well as sapropel-containing substrate BioDeposit Agro (BDA) had high biological activity towards growth promotion of vegetable seedlings. Sapropel water extracts had relatively high growth-enhancing component together with extremely low growth-inhibiting component.

2. Effect of sapropel on plant growth in pot experiments was species-specific, as substrate substitution at the optimum level of mineral supply resulted in significant increase in dry matter accumulation only in lettuce plants but not in winter rye plants.

3. Sapropel samples contained relatively high level of aerobic heterotrophic bacteria, high level of yeasts, and variable level of filamentous fungi with a low diversity. Plant growth-stimulating activity negatively correlated with the number of both yeasts and fungi. There were no correlation between the number of bacteria and plant growth stimulating activity.

\section{Acknowledgements}

LatPower Ltd. is acknowledged for a kind gift of sapropel and BioDeposit Agro samples used in the present study. The present study was partially supported by the ERDF funded project No. 2010/0292/2DP/2.1.1.1.0/10/ APIA/VIAA/122.

Received 30102013

Accepted 04082014

\section{References}

Angelova V. R., Ivanov K. I., Krustev S. V. 2008. Effect of phosphorus, organic and sapropel amendments on lead, zinc and cadmium uptake by Triticale from industrially polluted soils. Proceedings of the international conference on Soils, Sediments, Water and Energy, 13: 252-265

Appenroth K.-J., Stöckel J., Srivastava A., Strasser R. J. 2001. Multiple effects of chromate on the photosynthetic apparatus of Spirodela polyrhiza as probed by OJIP chlorophyll a fluorescence measurements. Environmental Pollution, 115: 49-64

http://dx.doi.org/10.1016/S0269-7491(01)00091-4

Arthur G. D., Stirk W. A., Novák O., Hekera P., van Staden J. 2007. Occurrence of nutrients and plant hormones (cytokinins and IAA) in the water fern Salvinia molesta during growth and composting. Environmental and Experimental Botany, 61: 137-144 http://dx.doi.org/10.1016/j.envexpbot.2007.05.002

Baker J. H. 1970. Quantitative study of yeasts and bacteria in a Signy Island peat. British Antarctic Service Bulletin, 23: $51-55$

Baksiene E. 2009. The influence of lake sediments on the fertility of Cambisol. Agronomy Research, 7: 175-182

Bevivino A., Sarrocco S., Dalmastri C., Tabacchioni S., Cantale C., Chiarini L. 1998. Characterization of a freeliving maize-rhizosphere population of Burkholderia cepacia: effect of seed treatment on disease suppression and growth promotion of maize. FEMS Microbiology Ecology, 27 (3): 225-237 http://dx.doi.org/10.1111/j.1574-6941.1998.tb00539.x

Chaoui H. I., Zibilske L. M., Ohno T. 2003. Effects of earthworm casts and compost on soil microbial activity and plant nutrient availability. Soil Biology and Biochemistry, 35: 295-302

http://dx.doi.org/10.1016/S0038-0717(02)00279-1

Coolen M. J. L., Cypionka H., Sass A. M., Sass H., Overmann J. 2002. Ongoing modification of Mediterranean Pleistocene sapropels mediated by prokaryotes. Science, 296: $2407-$ 2410 http://dx.doi.org/10.1126/science.1071893

Dzyuban A. N. 2002. Intensity of the microbiological processes of the methane cycle in different types of Baltic lakes. Microbiology, 71: 98-104 http://dx.doi.org/10.1023/A:1017910602635

Emeis K.-C., Weissert H. 2009. Tethyan-Mediterranean organic carbon-rich sediments from Mesozoic black shales to sapropels. Sedimentology, 56: 247-266 http://dx.doi.org/10.1111/j.1365-3091.2008.01026.x

Fritz J. I., Franke-Whittle I. H., Haindl S., Insam H., Braun R. 2012. Microbiological community analysis of vermicompost tea and its influence on the growth of vegetables and cereals. Canadian Journal of Microbiology, 58: $836-847$ http://dx.doi.org/10.1139/w2012-061

Grantina-Ievina L., Andersone U., Berkolde-Pīre D., Nikolajeva V., Ievinsh G. 2013. Critical tests for determination of microbiological quality and biological activity in commercial vermicompost samples of different origin. Applied Microbiology and Biotechnology, 97: 10541-10554

http://dx.doi.org/10.1007/s00253-013-4825-x 
Hunter P. J., Petch G. M., Calvo-Bado L. A., Pettitt T. R., Parsons N. R., Morgan J. A. W., Whipps J. M. 2006. Differences in microbial activity and microbial populations of peat associated with suppression of damping-off disease caused by Pythium sylvaticum. Applied and Environmental Microbiology, 72: 6452-6460

http://dx.doi.org/10.1128/AEM.00313-06

Ievinsh G. 2011. Vermicompost treatment differentially affects seed germination, seedling growth and physiological status of vegetable crop species. Plant Growth Regulation, 65: 169-181 http://dx.doi.org/10.1007/s10725-011-9586-x

Klavins M., Rodinov V., Druvietis I. 2003. Aquatic chemistry and humic substances in bog lakes in Latvia. Boreal Environmental Research, 8: 113-123

Kuznetsov S. I. 1975. The role of microorganisms in the formation of lake bottom deposits and their diagenesis. Soil Science, 119 (1): 81-88 http://dx.doi.org/10.1097/00010694-197501000-00012

Lee J. P., Lee S.-W., Kim C. S., Son J. H., Song J. H., Lee K. Y., Kim H. J., Jung S. J., Moon B. J. 2006. Evaluation of formulations of Bacillus licheniformis for the biological control of tomato gray mold caused by Botrytis cinerea. Biological Control, 37: 329-337 http://dx.doi.org/10.1016/j.biocontrol.2006.01.001

Liužinas R., Jankevičius K., Šalkauskas M., Mikalajūnas M. 2005. Improvement of lake sapropel quality: a new method. Geografijos metraštis, 38: 44-51

Nikolov N., Shaban N. 2011. Application of Black Sea sapropelles as amendment by growing of vegetable crop seedlings. Bulgarian Journal of Agricultural Science, 17: $167-172$

Orozco F. H., Cegarara J., Trujillo L. M., Roig A. 1996. Vermicomposting of coffee pulp using Eisenia fetida: effects on $\mathrm{C}$ and $\mathrm{N}$ contents and the availability of nutrients. Biology and Fertility of Soils, 22: 162-166 http://dx.doi.org/10.1007/BF00384449

Osvalde A. 2011. Optimization of plant mineral nutrition revisited: the roles of plant requirements, nutrient interactions, and soil properties in fertilization management. Environmental and Experimental Biology, 9: 1-8

Overmann J., Coolen M., Smock A., Sass H., Cypionka H. 1999. Microbial activities and populations in upper sediment and sapropel layers. Hieke W. et al. (eds). Meteor-Berichte 992. Universität Hamburg, Germany, p. 148-157

Piccolo A., Celano G., Pietramellara G. 1993. Effects of fractions of coal-derived humic susbtances on seed germination and growth of seedlings (Lactuga sativa and Lycopersicon esculentum). Biology and Fertility of Soils, 16: 11-15 http://dx.doi.org/10.1007/BF00336508

Prapagdee B., Chanprasert M., Mongkolsuk S. 2013. Bioaugmentation with cadmium-resistant plant growthpromoting rhizobacteria to assist cadmium phytoextraction by Helianthus annuus. Chemosphere, 92: 659-666 http://dx.doi.org/10.1016/j.chemosphere.2013.01.082

Süss J., Engelen B., Cypionka H., Sass H. 2004. Quantitative analysis of bacterial communities from Mediterranean sapropels based on cultivation-dependent methods. FEMS Microbiology Ecology, 51 (1): 109-121 http://dx.doi.org/10.1016/j.femsec.2004.07.010
Szajdak L., Maryganova V. 2007. Occurrence of IAA auxin in some organic soils. Agronomy Research, 5: 175-187

Terziev Z., Kirchev H., Semkova N. 2007. Results of potato field production using new granule fertilizers and amelioration containing sea sapropels. Research Journal of Agricultural Sciences, 39: 93-98

Tomati U., Grappelli A., Galli E. 1988. The hormone-like effect of earthworm casts on plant growth. Biology and Fertility of Soils, 5: 288-289 http://dx.doi.org/10.1007/BF00262133

Wurzbacher C.M., Bärlocher F., Grossart H.-P. 2010. Fungi in lake ecosystems. Aquatic Microbiological Ecology, 59: 125-149 http://dx.doi.org/10.3354/ame01385

Xu D., Liu D., Tang Z., Yu G., Yuan J., Shen Q., Huang Q. 2012. Structure of chemical components in different compost extracts characterized by chromatogram and spectroscopy analysis and its influence on plant growth promotion. Journal of Material Cycles and Waste Management, 14: $325-333$ http://dx.doi.org/10.1007/s10163-012-0071-z 
ISSN 1392-3196 / e-ISSN 2335-8947

Zemdirbyste-Agriculture, vol. 101, No. 4 (2014), p. 355-366

DOI 10.13080/z-a.2014.101.045

\title{
Gẻlavandenio sapropelio poveikis augalams, priklausomai nuo jo augalų augimą veikiančio aktyvumo ir mikroorganizmų bendrijų kiekio dirvožemyje
}

\author{
L. Grantina-Ievina, A. Karlsons, U. Andersone-Ozola, G. Ievinsh \\ Latvijos universitetas
}

\begin{abstract}
Santrauka
Turinčių daug organinių medžiagų sapropelio nuosėdų panaudojimas augalų vystymuisi yra gana plačiai tyrinètas, tačiau nėra pakankamai patvirtintas išsamių tyrimų rezultatais. Tyrimų tikslas - ištirti gėlavandenio sapropelio ir jo produktų biologinį aktyvumą, priklausomai nuo jų poveikio augalų vystymuisi ir mikroorganizmų bendrijų kiekio dirvožemyje. Be mineralinių mitybos elementų, sapropelyje nustatytos medžiagos, skatinančios augalų (burokèlių, griežčių, morkų ir pomidorų) augimą daigų vystymosi tarpsniu. Sapropelis ir juo papildytas substratas BioDeposit Agro turèjo santykinai daug augimą stimuliuojančių komponentų ir kartu itin mažai augimą slopinančių medžiagų. Substrato papildymas produktu BioDeposit Agro esmingai padidino sausųjų medžiagų sukaupimą salotų augaluose, tačiau to nebuvo nustatyta žieminiuose rugiuose. Visuose tirtuose sapropelio mėginiuose nustatytas didelis kiekis aerobinių heterotrofinių bakterijų bei mielių ir kintantis siūlinių grybų kiekis bei maža jų ịvairovè. Tirtų substratų augalų augimo stimuliavimas neigiamai koreliavo su mielių ir su grybų kolonijų kiekiu. Koreliacija tarp bakterijų kiekio ir augalų augimo stimuliavimo nebuvo nustatyta.
\end{abstract}

Reikšminiai žodžiai: augalų augimo stimuliavimas, dirvožemio gerinimas, kultivuojami mikroorganizmai, organinė trąša, sapropelis. 